\title{
Financial ratios used by equity analysts in Mexico and stock returns
}

\author{
Razones financieras usadas por analistas del mercado de capital \\ en México y rendimiento de acciones
}

\author{
Carlos Omar Trejo Pech ${ }^{\mathrm{a}, *}$, Magdy Noguera ${ }^{\mathrm{b}}$, Susan White ${ }^{\mathrm{c}}$ \\ ${ }^{a}$ Universidad Panamericana, School of Business and Economics, Mexico \\ ${ }^{\mathrm{b}}$ University of Idaho, College of Business and Economics, Department of Business, USA \\ ${ }^{c}$ University of Maryland, Robert H. Smith School of Business, Department of Finance, USA
}

Received 9 December 2014; accepted 26 February 2015

Available online 26 June 2015

\begin{abstract}
A sample of recommendation reports by equity analysts covering Mexican publicly traded firms in Mexico is studied. We propose a set of "most preferred" financial ratios from this sample. It is found that the most preferred ratios by equity analysts, a group of sophisticated users, are not those ratios typically covered in financial textbooks. Moreover, by using panel regression analysis, we test the relationship between financial ratios and leading stock returns during the 1995-2011 period. Overall, consistent with the efficient market hypothesis, the results show that estimates of financial ratios most preferred by equity analysts have predictive power on 1-year future stock returns. We find no evidence of predictive power on 2-year stock returns.

All Rights Reserved (C) 2015 Universidad Nacional Autónoma de México, Facultad de Contaduría y Administración. This is an open access item distributed under the Creative Commons CC License BY-NC-ND 4.0.
\end{abstract}

Keywords: Financial ratios; Equity analysts; Mexican firms; Panel regression

\section{Resumen}

Se estudia una muestra de recomendaciones por analistas del mercado de capital en México. Proponemos un grupo de razones financieras "preferidas" en base a esa muestra. Encontramos que las razones financieras preferidas de los analistas, un grupo sofisticado de usuarios de información financiera, no son aquellas

\footnotetext{
* Corresponding author.

E-mail address: ctrejo@up.edu.mx (C.O. Trejo Pech).

Peer Review under the responsibility of Universidad Nacional Autónoma de México.
} 
típicamente incluidas en los libros de texto de finanzas. Más aún, usando análisis de regresión de panel, probamos estadísticamente la relación entre razones financieras y rendimientos futuros de acciones durante el periodo de 1995-2011. En general, en consistencia con la hipótesis de mercados eficientes, los resultados muestran que los coeficientes de las razones financieras preferidas por analistas tienen capacidad predictiva sobre rendimientos futuros a un año. No encontramos evidencia de capacidad predictiva en rendimientos a dos años.

Derechos Reservados (C) 2015 Universidad Nacional Autónoma de México, Facultad de Contaduría y Administración. Este es un artículo de acceso abierto distribuido bajo los términos de la Licencia Creative Commons CC BY-NC-ND 4.0.

Palabras clave: Razones financieras; Analistas financieros; Empresas Mexicanas; Regresiones de panel

\section{Introduction}

The purpose of this article is twofold; to propose a set of "most preferred" financial ratios and to test the relationship between financial ratios and stock returns. We select sets of financial ratios from a sample of recommendation reports by leading equity analysts. Then, we test a model on which stock returns are regressed on financial ratios. Results are discussed in terms of financial theory.

Two sets of results are provided: (1) most preferred financial ratios by equity analysts in Mexico, and (2) econometric tests on the relation of financial ratios and future stock returns. Results of this study might be of importance for diverse users of financial ratios (e.g., academics, corporate managers, banks). The high number of financial ratios used in practice could confuse users due to overlapping information. Thus, a reduced set, selected from a group of sophisticated users (e.g., equity analysts), might be valuable by itself. This information set is additionally valuable for the predictive ability of the selected ratios.

Overall, our proposed sets of most preferred ratios have predictive power, and the estimators have the signs as predicted by theory; supporting the proposition that those ratios indeed represent a set of valuable financial information. By using results from this study, users could become more selective about the information to use for financial analysis. Equity analysts would be interested in which ratios were used by competitors and firms interested in which ratios were used by equity analysts, which could lead to improved decision making by both parties. Moreover, since the literature on the use of financial ratios is scarce and focused primarily on the US market, we contribute to the finance literature.

\section{Literature review}

A recurring research question has been whether financial ratios predict firm performance. Wang and Lee (2010) used financial ratio categories (leverage, solvency, turnover, and profitability) to create a matrix that provide an estimate of the strength of a firm within the shipping industry in Taiwan. Recently, in a similar study of the U.S. agricultural industry, Katchova and Enlow (2013) used the DuPont ratios to compare return on equity components of agribusiness firms, finding that asset turnover was the most predictive ratio, leading to a stronger financial performance. In general, financial ratios have been used as inputs to forecast a number of business related situations such as financial distress, credit ratings, risk, future cash flows, among others (Beaver, 1966; Call, 2008). 
A popular research area has been investigating the statistical relationship between financial ratios and stock returns since ratios are perceived as useful in forecasting future rates of returns (Barnes, 1987). Literature on stock predictability has evolved over the past few decades. Initial evidence that market returns are predictable was questioned by later studies that found such predictions did not hold in subsamples. Nonetheless, once methodological corrections have been made, some financial ratios, particularly dividend yield, earnings per share, and book to market value of equity have been found to consistently forecast market returns for long periods (Lewellen, 2004). ${ }^{1}$ A challenge on those studies is the selection of financial ratios to test since ratios tend to contain overlapping information.

A group of researchers has relied on statistical techniques to tease the relevant information out. Delen, Kuzey, \& Uyar (2013) first used factor analysis to identify underlying dimensions of the ratios, followed by predictive modeling methods to determine relationships between firm performance and financial ratios. The authors found that the earnings before tax to equity ratio and net profit margin were the two most important variables in predicting future performance. Chen and Shimerda (1981) employed principal component analysis to 34 financial ratios that were useful in various studies on prediction of bankruptcy and found that all ratios were highly correlated to seven major factors. That is, many ratios revealed the same information. Such findings indicate that there is an opportunity to reduce the number of ratios employed to a much more limited but still representative set.

As an empirical alternative to factor analysis, researchers have surveyed security analysts about their opinion of the usefulness of financial ratios. Matsumoto, Shivaswamy, \& Hoban (1995) surveyed security analysts, asking them to assume that they were analyzing a NYSE-listed firm. Analysts were asked to rate, in a 1-5 Likert-type scale, the usefulness of 63 financial ratios organized into 13 groups. The authors reported that the most important ratios were growth rates such as earnings per share (EPS) growth and sales growth, followed by valuation ratios (Price to Earnings and Market to Book), profitability ratios, and leverage ratios. Inventory turnover, receivables turnover, cash flow ratios and dividend ratios were moderately important with capital turnover and cash position ratios the least important. Gibson (1987) conducted a survey among Certified Financial Analysts charter-holders and found that analysts assigned the highest significance ratings to profitability ratios followed by the Price to Earnings ratio. Debt ratios, liquidity ratios and the rest of "other ratios" are lower in importance.

In this study, we test the relationship between sets of selected financial ratios and stock returns of firms in the Mexican Stock Exchange index. To select financial ratios, a sample of recommendation reports by equity analysts is studied. Unlike previous studies, our set of financial ratios is comprehensive as it includes all categories of ratios used in practice by a group of sophisticated financial users. Two sets of results are provided: (1) most preferred financial ratios by equity analysts in Mexico, and (2) econometric tests on the relation of financial ratios and future stock returns.

Our results on the most preferred financial ratios are, in general, consistent with Matsumoto et al. (1995) and Gibson (1987) as we find that valuation, profitability, and leverage ratios are the most used categories by research analysts following equities listed on the Mexican stock exchange. However, our findings differ about the relative importance of types of ratios. Furthermore, unlike

\footnotetext{
${ }^{1}$ An alternative string of research, out of the scope of this study, has challenged assets pricing models and investigated whether some financial have explanatory power beyond market betas. Fama and French (1992) documented the most significant finding in this area; they show that an asset pricing model incorporating Book to Market and Market Capitalization (e.g., Fama and French Three Factors Model) improves the Capital Asset Pricing Model.
} 
previous research, we document that cash flow related ratios such as free cash flow yield and dividend yield, are of relatively high importance to financial analysts. In addition, our selection of preferred ratios based on analysts' reports and recommendations have predictive power in terms of future $t+4$ (i.e., 1-year ahead) stock returns, with signs of estimators according to financial theory.

\section{Data}

We use two types of data: recommendation reports by equity analysts, and historical financial statement data and stocks prices of publicly traded Mexican firms.

\section{Recommendation reports by equity analysts}

Recommendation reports were obtained during the first quarter of 2011 from ISI Emerging Markets (ISI). ${ }^{2}$ All equity reports available on ISI, with an explicit buy, hold, or sell recommendation, were retrieved. The sample, 72 reports, from 40 firms, was restricted to non-financial firms trading on the Mexican Stock Exchange (MSE). ${ }^{3}$ Appendix 1 shows firms in the sample and presents some of their general characteristics including industry, annual revenues, and an indication of whether the firm was part of the MSE index or not. The MSE index contained 35 equity as of April 2011, with 6 financial firms and 29 non-financial firms. Of the 40 firms in our sample, for the regression analysis, we use the 29 non-financial firms that were part of the MSE index, implying that our sample represents the Mexican Stock Exchange market. Equity analysts are from J.P. Morgan, HSBC Global Research, Credit Suisse, among others.

\section{Accounting data and stock prices}

Accounting data and stock prices, from 1995 to 2011, are from Economatica. We use quarterly data, with variables from the income statement and the statement of cash flow annualized every quarter. That is, quarterly data are converted to trailing 12 months (TTM) data by adding figures from the current and previous three quarters to avoid within-year seasonality effects. This sample, used for the regression analysis, includes about 1150 firm-TTM observations.

\section{Methods}

\section{Most preferred financial ratios}

We use the recommendation reports sample to select the most preferred financial ratios. We find that equity analysts in the sample use standard templates, with the same financial ratios, regardless of the firm or industry covered. We assume they include financial ratios of their preference in

\footnotetext{
${ }^{2}$ ISI Emerging Markets gathers business and economic reports for the use of paid subscribers. In particular, we searched in the "Analysis/Research: Company" section of ISI Emerging Markets Mexico. ISI Emerging Markets Mexico used to provide equity analysts recommendation reports as referred here. To the best of our knowledge, these reports are not provided any more by this company.

${ }^{3}$ From an initial sample of 111 financial reports, we excluded from the sample reports without a recommendation and quarterly conference call reports. Most reports in the sample are dated February and March 2011, as firms were preparing to submit or had recently submitted their annual financial reports for the period ending December 31, 2010.
} 
their firm's standard template. Thus, we count the financial ratios used by analysts in the sample. While simple, this way of selecting the most used (preferred) financial ratios is straightforward and objective. Table 1 provides the frequency of use. Financial ratios are categorized as accounting ratios, valuation ratios or multiples; cash flow ratios, and other ratios. Accounting ratios are further grouped into profitability ratios and margins, and leverage or debt management ratios. ${ }^{4}$

We define "most preferred" ratios as those that are used by $50 \%$ or more of the analysts in the sample. ${ }^{5}$ This reduces the set from 36 ratios used in practice by equity analysts, according to the sample, to fourteen most preferred ratios, summarized in Table $2 .^{6}$

\section{Regressions}

Our main interest is to examine whether the most preferred financial ratios used by equity analysts might predict stock performance. We use a two-way random effects model for our regression analysis. The regression model we estimate takes the form:

$$
R E T_{t+n}=\alpha+\beta_{1} F I_{t}+\beta_{2} \log (M V E)+\beta_{3} B E T A_{t+n}+\varepsilon
$$

where RET is stock return at quarter $t+n ; n$ is 4 for 1 year future returns or 8 for 2 years. FI are alternative sets of most preferred financial ratios (specified in the next section) at quarter $t$ and $\log (M V E)$, the logarithm of the market capitalization of the firm's equity, and BETA, the measure of systematic risk, act as control variables. Variables for Eq. (1) are computed using accounting data and stock prices obtained from Economatica, from 1995 to 2011, for firms included in the MSE index.

We control for serial correlation and heteroscedasticity using the Newey-West correction of standard errors. ${ }^{7}$

Table 3 provides descriptive statistics and Table 4 provides Pearson correlation coefficients of the main variables used in the study. These correlation coefficients help to avoid the inclusion of highly correlated variables in the models, as we explain next.

We have five FI categories (e.g., valuation, profit and margins, etc.). To reduce multicollinearity, alternative models are run with one variable per category. To avoid redundancy of information, and to have the number of variables/models manageable and results feasible to discuss in

\footnotetext{
${ }^{4}$ Financial ratios involve the income statement and the balance sheet only, with the exception of leverage ratios which use market capitalization instead of book value of equity. Valuation ratios or multiples combine figures from the income statement or balance sheet with market stock prices. Cash flow ratios use figures from the cash flow statement. Per share data and growth indicators were placed in the "Other" category.

5 While this $50 \%$ cut-off is arbitrary, it has some intuition and some level of representativeness. First, it means that from the 72 equity reports, among the 10 equity analysts, a "most preferred" financial ratio is used at least by half of the analysts (we are not allowing double counting, as could be observed from Table 1). This selection is also convenient, as it allows to have at least two ratios per category, as Table 2 shows, which in turn, allows to include financial ratios of all categories in the regression tests, and have alternative ratios within categories.

6 As a cross-check, we also analyzed only those recommendation reports with upgrades or downgrades. That is, when there was a change in the recommendation; for instance, from hold to buy. However, as the sample of reports with changes is very small, with only 12 observations in the sample, generalizations cannot be made and we do not tabulate/discuss in detail these results. The analysis, nevertheless, reinforces two points: (a) the main financial ratios that influence change in recommendation (e.g., EBITDA margin growth, EPS growth, sales growth) are also in our list of most preferred ratios (Table 2), and (b) while equity analysts use standard templates, they tailor their analysis to the company they assess by emphasizing different ratios.

7 Alternatively, we ran Arellano (1987) heteroscedasticity-corrected covariance matrices estimators (HCCME) with cluster correction. We find results similar to those reported in Table 5.
} 
Table 1

Frequency of financial ratios used by the analysts covering Mexican equities.

\begin{tabular}{|c|c|c|c|c|c|c|c|c|c|c|c|}
\hline $\begin{array}{l}\text { Financial } \\
\text { indicator } \backslash \text { analyst }\end{array}$ & BBVA & $\mathrm{CS}$ & $\mathrm{BB} \& \mathrm{~T}$ & DB & HSBC & Itau & JPM & MT & ST & VE & Total \\
\hline $\begin{array}{l}\text { Number of } \\
\text { recommendations }\end{array}$ & 8 & 15 & 1 & 9 & 15 & 8 & 4 & 1 & 7 & 4 & 72 \\
\hline \multicolumn{12}{|c|}{ Profitability ratios and margins } \\
\hline EBITDA margin & $\mathrm{X}$ & $\mathrm{X}$ & $\mathrm{X}$ & $\mathrm{X}$ & $\mathrm{X}$ & $X$ & & & $\mathrm{X}$ & & 7 \\
\hline $\begin{array}{l}\text { Return on equity } \\
\text { (ROE) }\end{array}$ & $\mathrm{X}$ & $\mathrm{X}$ & $\mathrm{X}$ & $\mathrm{X}$ & $\mathrm{X}$ & $\mathrm{X}$ & $\mathrm{X}$ & & & & 7 \\
\hline EBIT margin & & $\mathrm{X}$ & & $\mathrm{X}$ & $\mathrm{X}$ & $\mathrm{X}$ & & & $\mathrm{X}$ & & 5 \\
\hline $\begin{array}{l}\text { Return on } \\
\text { investment } \\
\text { (ROI) }\end{array}$ & $\mathrm{X}$ & $\mathrm{X}$ & & & $\mathrm{X}$ & $\mathrm{X}$ & $\mathrm{X}$ & & & & 5 \\
\hline $\begin{array}{l}\text { Return on assets } \\
\text { (ROA) }\end{array}$ & & & & $\mathrm{X}$ & $\mathrm{X}$ & $\mathrm{X}$ & $\mathrm{X}$ & & & & 4 \\
\hline $\begin{array}{l}\text { Revenue to } \\
\text { invested capital }\end{array}$ & & & & & $\mathrm{X}$ & & & & & & 1 \\
\hline Extended DuPont & & & & $\mathrm{X}$ & & & & & & & 1 \\
\hline \multicolumn{12}{|c|}{ Leverage or debt management } \\
\hline $\begin{array}{l}\text { Net debt to } \\
\text { EBITDA }\end{array}$ & $\mathrm{X}$ & $\mathrm{X}$ & & & $\mathrm{X}$ & $\mathrm{X}$ & & $\mathrm{X}$ & & & 5 \\
\hline Net debt to equity & & $\mathrm{X}$ & & $\mathrm{X}$ & $\mathrm{X}$ & $\mathrm{X}$ & & & $\mathrm{X}$ & & 5 \\
\hline Interest coverage & $\mathrm{X}$ & & & $\mathrm{X}$ & & $X$ & & & & & 3 \\
\hline $\begin{array}{l}\text { EBITDA to net } \\
\text { interest } \\
\text { expenses }\end{array}$ & & $\mathrm{X}$ & & & $\mathrm{X}$ & & & & & & 2 \\
\hline $\begin{array}{l}\text { Net debt to total } \\
\text { capitalization }\end{array}$ & & & & & & $\mathrm{X}$ & & & & & 1 \\
\hline $\begin{array}{l}\text { Debt to total } \\
\text { capitalization }\end{array}$ & & & $\mathrm{X}$ & & & & & & & & 1 \\
\hline Assets to equity & & & & & & & $X$ & & & & 1 \\
\hline $\begin{array}{l}\text { Cash flows from } \\
\text { op. to net debt }\end{array}$ & & & & & $\mathrm{X}$ & & & & & & 1 \\
\hline \multicolumn{12}{|c|}{ Multiples or valuation ratios } \\
\hline $\begin{array}{l}\text { Price to earnings } \\
\text { (PE) }\end{array}$ & $\mathrm{X}$ & $\mathrm{X}$ & $\mathrm{X}$ & $\mathrm{X}$ & $\mathrm{X}$ & $\mathrm{X}$ & & $\mathrm{X}$ & $\mathrm{X}$ & $\mathrm{X}$ & 9 \\
\hline $\begin{array}{l}\text { Firm value }(\mathrm{FV}) \\
\text { to EBITDA }\end{array}$ & $\mathrm{X}$ & $\mathrm{X}$ & $\mathrm{X}$ & $\mathrm{X}$ & $\mathrm{X}$ & $\mathrm{X}$ & $\mathrm{X}$ & $\mathrm{X}$ & $\mathrm{X}$ & & 9 \\
\hline $\begin{array}{l}\text { Price to book } \\
\text { value }\end{array}$ & $\mathrm{X}$ & $\mathrm{X}$ & & $\mathrm{X}$ & $\mathrm{X}$ & $\mathrm{X}$ & $\mathrm{X}$ & & & $\mathrm{X}$ & 7 \\
\hline Price to sales & & & & $X$ & & & & & $X$ & $\mathrm{X}$ & 3 \\
\hline $\begin{array}{l}\text { Firm value }(\mathrm{FV}) \\
\quad \text { to sales }\end{array}$ & $\mathrm{X}$ & & & & $\mathrm{X}$ & & & & $\mathrm{X}$ & & 3 \\
\hline $\begin{array}{l}\text { Firm value }(\mathrm{FV}) \\
\text { to EBIT }\end{array}$ & & & & $\mathrm{X}$ & & $\mathrm{X}$ & & & & & 2 \\
\hline $\begin{array}{l}\text { FV to invested } \\
\text { capital }\end{array}$ & & $\mathrm{X}$ & & & $\mathrm{X}$ & & & & & & 2 \\
\hline $\begin{array}{l}\text { Price to capital } \\
\text { employed }\end{array}$ & & & & & & & & & $\mathrm{X}$ & & 1 \\
\hline \multicolumn{12}{|l|}{ Cash flows } \\
\hline Dividend yield & $X$ & $X$ & & $\mathrm{X}$ & $X$ & $\mathrm{X}$ & $\mathrm{X}$ & $\mathrm{X}$ & $X$ & & 8 \\
\hline $\begin{array}{l}\text { Free cash flow } \\
(\mathrm{FCF}) \text { yield }\end{array}$ & $\mathrm{X}$ & $\mathrm{X}$ & & $\mathrm{X}$ & $\mathrm{X}$ & & $\mathrm{X}$ & $\mathrm{X}$ & $\mathrm{X}$ & & 7 \\
\hline Dividends payout & $X$ & & & $\mathrm{X}$ & & & & & & & 2 \\
\hline
\end{tabular}


Table 1 (Continued)

\begin{tabular}{|c|c|c|c|c|c|c|c|c|c|c|c|}
\hline $\begin{array}{l}\text { Financial } \\
\text { indicator } \backslash \text { analyst } \\
\text { Number of } \\
\text { recommendations }\end{array}$ & BBVA & $\mathrm{CS}$ & $\mathrm{BB} \& \mathrm{~T}$ & DB & HSBC & Itau & JPM & MT & ST & VE & 72 \\
\hline $\begin{array}{l}\text { Working capital to } \\
\text { sales }\end{array}$ & & & & & & & $\mathrm{X}$ & & & & 1 \\
\hline $\begin{array}{l}\text { CAPEX to } \\
\text { operating cash } \\
\text { flow }\end{array}$ & & $\mathrm{X}$ & & & & & & & & & 1 \\
\hline $\begin{array}{l}\text { CAPEX to dep. \& } \\
\text { amortization }\end{array}$ & & & & & & & $X$ & & & & 1 \\
\hline CAPEX to sales & & & & & & & $\mathrm{X}$ & & & & 1 \\
\hline \multicolumn{12}{|l|}{ Other } \\
\hline $\begin{array}{l}\text { Earnings per share } \\
\text { (EPS) }\end{array}$ & $\mathrm{X}$ & $\mathrm{X}$ & $\mathrm{X}$ & $X$ & $\mathrm{X}$ & $\mathrm{X}$ & $\mathrm{X}$ & $X$ & $X$ & $\mathrm{X}$ & 10 \\
\hline Sales growth & $X$ & $\mathrm{X}$ & & $\mathrm{X}$ & $\mathrm{X}$ & $\mathrm{X}$ & $X$ & $X$ & $\mathrm{X}$ & & 8 \\
\hline $\begin{array}{l}\text { Dividends per } \\
\text { share }\end{array}$ & $X$ & & & $\mathrm{X}$ & $\mathrm{X}$ & $\mathrm{X}$ & $\mathrm{X}$ & & $\mathrm{X}$ & $\mathrm{X}$ & 7 \\
\hline $\begin{array}{l}\text { Earnings per share } \\
\text { (EPS) growth }\end{array}$ & $\mathrm{X}$ & & & $\mathrm{X}$ & $\mathrm{X}$ & & & $\mathrm{X}$ & $X$ & $\mathrm{X}$ & 6 \\
\hline $\begin{array}{l}\text { Free cash flow } \\
\text { (FCF) growth }\end{array}$ & & & $\mathrm{X}$ & $\mathrm{X}$ & & & $\mathrm{X}$ & $\mathrm{X}$ & & & 4 \\
\hline $\begin{array}{l}\text { Free cash flow } \\
\qquad(\mathrm{FCF}) \text { per share }\end{array}$ & & & $\mathrm{X}$ & $\mathrm{X}$ & & & & & & & 2 \\
\hline
\end{tabular}

BBVA stands for BBVA Bancomer; CS is Credit Suisse; BB\&T is BB\&T Capital Markets; DB is Deutsche Bank; HSBC is HSBC Global Research; Itau is Itaú BBA; JPM is J.P. Morgan; MT is Miller Tabak + Comp.; ST is Santander; VE is ValuEngine.

EBITDA is earnings before interest, taxes, depreciation, and amortization; EBIT is earnings before interest and taxes; Net Debt is debt minus cash; CAPEX is capital expenditures. Financial ratios might be calculated slightly different among financial analysts (most analysts do not disclose their formulas). In Table 3, we specify how financial ratios are estimated for the empirical results in this study.

this article, we reduce the number of most preferred ratios from Table 2 following two criteria. (1) Financial ratios with high correlation coefficients are excluded from the models and (2) when two variables are similar, the most theoretically robust variable is included in the models.

Table 2

Most preferred financial ratios by frequency of use among equity analysts.

\begin{tabular}{lll}
\hline Profitability and margins & Valuation or multiples & Cash flow \\
EBITDA margin (7) & Price to earnings (9) & Dividend yield (8) \\
Return on equity - ROE (7) & Firm value (FV) to EBITDA (9) & Free cash flow yield (7) \\
Return on investment - ROI (5) & Price to book value (7) \\
EBIT margin (5) & & \\
Leverage or debt management & & Other \\
Net debt to EBITDA (5) & & EPS (and EPS growth) (10) \\
Net debt to equity (5) & Sales growth (8) \\
& & Dividends per share (7) \\
\hline
\end{tabular}

Frequency of use of financial ratio among equity analysts, out of ten, indicated in parenthesis. Financial ratios might be calculated slightly different among financial analysts (most analysts do not disclose their formulas). In Table 3, we specify how financial ratios are estimated for the empirical results in this study. 
Table 3

Descriptive statistics.

\begin{tabular}{|c|c|c|c|c|c|}
\hline Variable & $N$ & Mean & Std dev & Minimum & Maximum \\
\hline Stock returns, $t+4$ & 1138 & 0.28 & 0.58 & -0.91 & 5.04 \\
\hline Stock returns, $t+8$ & 1016 & 0.21 & 0.55 & -0.91 & 5.04 \\
\hline Price to earnings & 1155 & 15.70 & 54.77 & -511.14 & 910.43 \\
\hline Firm value to EBITDA & 1155 & 7.94 & 17.77 & -363.27 & 325.95 \\
\hline EBITDA margin & 1155 & 0.43 & 0.87 & -0.01 & 7.51 \\
\hline ROI & 1155 & 0.08 & 0.49 & -9.11 & 10.07 \\
\hline Dividend yield & 1155 & -0.04 & 0.12 & -0.80 & 1.00 \\
\hline Free cash flow yield & 1155 & 0.18 & 0.74 & -3.61 & 14.30 \\
\hline Net debt to equity & 1155 & 0.92 & 0.73 & -0.17 & 4.12 \\
\hline Earnings per share growth & 1155 & 0.08 & 1.42 & -17.13 & 25.58 \\
\hline Sales growth & 1155 & 0.09 & 1.32 & -0.98 & 43.97 \\
\hline $\mathrm{ROE}$ & 1155 & 0.12 & 0.16 & -1.47 & 0.69 \\
\hline Net debt_to_EBITDA & 1155 & 2.65 & 12.15 & -298.51 & 194.27 \\
\hline Dividends per share & 1155 & -0.06 & 0.16 & -2.04 & 0.77 \\
\hline Price to book & 1155 & 2.18 & 3.83 & 0.01 & 35.84 \\
\hline EBIT margin & 1155 & 0.35 & 0.81 & -0.33 & 8.08 \\
\hline
\end{tabular}

Variables are estimated as follows. Stock Return is the change in prices (price in year t divided by price in year $t-1$ ) one-year $(t+4)$ and two-years ahead $(t+8)$. Price to earnings is stock price as of the end of the quarter divided by trailing 12 months (TTM) earnings per share. Firm value to EBITDA is firm value, defined as market capitalization (stock price times number of shares outstanding) plus total liabilities minus cash and short term investments, all divided by TTM earnings before interest, taxes, depreciation and amortization (EBITDA). EBITDA margin is TTM EBITDA divided by TTM revenues. ROI is return on investment, defined as TTM net operating profits after taxes divided by investment, where investment is common equity plus short term debt plus long term debt minus cash and short term investments. Dividend yield is dividends paid per share divided by stock price. Free cash flow yield is free cash flow per share, defined as TTM cash flow from operations minus TTM net investment in property, plant and equipment (Net CAPEX) divided by common shares outstanding, divided by stock price. Net debt to equity is total liabilities minus cash and short term investments, all divided by common equity. Earnings per share growth is the change of the ratio of net earnings divided by number of shares outstanding. Sales growth is the change of TTM revenues. ROE is net income divided by common equity. Net debt to EBITDA is total liabilities minus cash and short term investments, all divided by TTM EBITDA. Dividends per share is dividends paid divided by shares outstanding. Price to book is stock price divided by the common equity per share outstanding. EBIT margin is earnings before interest and taxes divided by revenues.

First, ROE is statistically correlated with all financial ratios, but FCFY and Sales g (Table 4), so it is excluded from the regressions. Between EBITDA margin and EBIT margin, similar ratios, the former is chosen since it contains additional valuable information (depreciation and amortization). FV to EBITDA is chosen over price to earnings because the former is a more comprehensive measure than $P / E$, capturing both the relationship between market price and earnings and leverage. Net Debt to EBITDA is also excluded as the correlation between FV to EBITDA and Net Debt to EBITDA is very high (0.92, Table 4), and FV to EBITDA is used by 9 out of 10 equity analysts. Finally, dividends per share is considered redundant for the regressions as we have dividends yield and price to earnings per share. Thus, we use eight models for the empirical tests. ${ }^{8}$

Model 1: FV EBITDA, EBITDA margin, dividend yield, net debt to equity, EPS growth, Model 2: FV EBITDA, EBITDA margin, dividend yield, net debt to equity, sales growth, Model 3: FV EBITDA, EBITDA margin, FCF yield, net debt to equity, EPS growth,

\footnotetext{
${ }^{8}$ For the remaining variables, multicollinearity was also tested using variance inflation factor (VIF). No multicollinearity was found. VIFs for most variables are between 1.00 and 2.00.
} 
Table 4

Pearson correlation coefficients.

\begin{tabular}{|c|c|c|c|c|c|c|c|c|c|c|c|c|c|c|}
\hline & P_E & FV EB & EBD M & ROI & DIVY & FCF Y & DEQ & EPS $g$ & Sales g & ROE & DEB & DPS & PB & ЕВIT\% \\
\hline P_E & 1.00 & $0.09^{* * * *}$ & 0.02 & 0.04 & $0.06^{* * *}$ & $-0.06^{* * *}$ & $0.07^{* *}$ & -0.01 & 0.00 & 0.03 & -0.01 & 0.03 & $0.52^{\text {**** }}$ & 0.02 \\
\hline FV EB & $0.09^{* * *}$ & 1.00 & $-0.10^{* * * *}$ & -0.02 & $0.09^{\text {**** }}$ & $-0.09^{* * * *}$ & $0.11^{* * *}$ & 0.02 & -0.01 & $-0.09^{\text {***** }}$ & $0.92^{\text {**** }}$ & 0.04 & $0.18^{* * *}$ & $-0.10^{* * * *}$ \\
\hline EBD M & 0.02 & $-0.10^{* * * *}$ & 1.00 & $0.30^{* * *}$ & $-0.30^{* * * *}$ & $0.19^{* * * *}$ & -0.01 & 0.02 & -0.01 & $0.16^{\text {**** }}$ & $-0.05^{* *}$ & 0.00 & 0.03 & $0.98^{* * *}$ \\
\hline ROI & 0.04 & -0.02 & $0.30^{* * * *}$ & 1.00 & $-0.09^{\text {**** }}$ & $0.05^{*}$ & 0.02 & -0.01 & 0.00 & $0.07^{* *}$ & -0.02 & 0.01 & $0.09^{* * * *}$ & $0.30^{* * * *}$ \\
\hline DIVY & $0.06^{* *}$ & $0.09^{* * * *}$ & $-0.30^{* * * *}$ & $-0.09^{* * * *}$ & 1.00 & $0.06^{* *}$ & $0.12^{* * *}$ & 0.01 & -0.01 & $-0.06^{* *}$ & 0.03 & $0.39^{* * *}$ & $0.13^{* * *}$ & $-0.29^{\text {**** }}$ \\
\hline FCF Y & $-0.06^{* * *}$ & $-0.09^{* * * *}$ & $0.19^{* * * *}$ & $0.05^{*}$ & $0.06^{* *}$ & 1.00 & 0.00 & -0.01 & -0.01 & 0.03 & -0.02 & 0.03 & $-0.11^{* * * *}$ & $0.19^{* * * *}$ \\
\hline DEQ & $0.07^{* * *}$ & $0.11^{\text {**** }}$ & -0.01 & 0.02 & $0.12^{\text {***** }}$ & 0.00 & 1.00 & $0.08^{* * * *}$ & 0.02 & $-0.06^{* *}$ & $0.11^{* * * *}$ & $0.13^{* * *}$ & $0.31^{* * * *}$ & -0.02 \\
\hline EPS $g$ & -0.01 & 0.02 & 0.02 & -0.01 & 0.01 & -0.01 & $0.08^{* * * *}$ & 1.00 & -0.01 & $-0.20^{* * * *}$ & 0.03 & 0.02 & -0.01 & 0.01 \\
\hline Sales $g$ & 0.00 & -0.01 & -0.01 & 0.00 & -0.01 & -0.01 & 0.02 & -0.01 & 1.00 & -0.02 & 0.00 & 0.00 & -0.01 & -0.01 \\
\hline ROE & 0.03 & $-0.09^{\text {**** }}$ & $0.16^{* * * *}$ & $0.07^{* *}$ & $-0.06^{* * *}$ & 0.03 & $-0.06^{* *}$ & $-0.20^{\text {***** }}$ & -0.02 & 1.00 & $-0.09^{* * * *}$ & $-0.12^{* * * *}$ & $0.13^{\text {***** }}$ & $0.15^{\text {*** }}$ \\
\hline DEB & -0.01 & $0.92^{* * * *}$ & $-0.05^{*}$ & -0.02 & 0.03 & -0.02 & $0.11^{* * * *}$ & 0.03 & 0.00 & $-0.09^{* * * *}$ & 1.00 & 0.03 & 0.00 & $-0.05^{*}$ \\
\hline DPS & 0.03 & 0.04 & 0.00 & 0.01 & $0.39^{* * * *}$ & 0.03 & $0.13^{* * * *}$ & 0.02 & 0.00 & $-0.12^{* * * *}$ & 0.03 & 1.00 & 0.04 & 0.00 \\
\hline PB & $0.52^{* * * *}$ & $0.18^{* * * *}$ & 0.03 & $0.09^{\text {***** }}$ & $0.13^{\text {**** }}$ & $-0.11^{* * * *}$ & $0.31^{* * *}$ & -0.01 & -0.01 & $0.13^{\text {**** }}$ & 0.00 & 0.04 & 1.00 & 0.03 \\
\hline EBIT\% & 0.02 & $-0.10^{* * * *}$ & $0.98^{* * * *}$ & $0.30^{* * * *}$ & $-0.29^{* * * *}$ & $0.19^{* * *}$ & -0.02 & 0.01 & -0.01 & $0.15^{* * * * *}$ & $-0.05^{*}$ & 0.00 & 0.03 & 1.00 \\
\hline
\end{tabular}

$\mathrm{PE}$ is price to earnings, FV EB is firm value to EBITDA, EBD M is EBITDA margin, ROI is return on investment, DivY is dividend yield, FCF Y is free cash flow yield, DEQ is net debt to equity, EPS $\mathrm{g}$ is earnings per share growth, Sales $\mathrm{g}$ is sales growth, ROE is return on equity, DEB is net debt to EBITDA, DPS is dividends per share, PB is price to book, and EBIT\% is EBIT margin.

Variables estimated as stated in Table 3.

*** $1 \%$ statistical significance level.

** $5 \%$ statistical significance level.

* $10 \%$ statistical significance level. 
Model 4: FV EBITDA, EBITDA margin, FCF yield, net debt to equity, sales growth,

Model 5: FV EBITDA, ROI, dividend yield, net debt to equity, EPS growth,

Model 6: FV EBITDA, ROI, dividend yield, net debt to equity, sales growth,

Model 7: FV EBITDA, ROI, FCF yield, net debt to equity, EPS growth, and

Model 8: FV EBITDA, ROI, FCF yield, net debt to equity, sales growth.

\section{Results}

\section{Most preferred financial ratios}

Tables 1 and 2 show the most preferred financial ratios used by equity analysts. This differs from what a typical financial textbook presents, especially pertaining to accounting ratios. Accounting ratios are usually classified in textbooks as profitability and margin ratios, asset turnover or efficiency ratios, liquidity, and leverage or management ratios. Equity analysts in this sample do not use liquidity or asset turnover ratios; instead, they concentrate on profitability and margins, and leverage. Probably equity analysts use cash flow related ratios as better substitutes for turnover and liquidity ratios.

Net debt to EBITDA and net debt to equity are the debt management ratios preferred by analysts. Textbooks, in general, do not mention net debt (defined as debt minus cash and cash equivalents), or net debt to EBITDA. This may be because net debt is used more by practitioners than by academics and instructors according to Bates, Kahle, \& Stulz (1999).

Concerning valuation ratios or multiples, price to earnings (PE), firm value (FV) to EBITDA, and price to book value $(P / B)$ are by far the most preferred multiples. Among cash flow ratios, dividend yield and free cash flow yield are most preferred. ${ }^{9}$ In general, cash flow ratios, are as common, in terms of frequency of use, as earnings and price related ratios. This supports the idea that cash flows are at least as important as earnings. Furthermore, we observed that, with one exception, all analysts in the sample included cash flow statements projections in their reports, implying that cash flow metrics are highly valued by equity analysts. Concerning this, Call, Chen, \& Tong (2009) suggest that earnings forecasts of analysts accompanied by cash flow forecasts could be more accurate than earnings forecasts without cash flow forecasts.

In the "Other" category, earnings per share (EPS), sales growth, and dividends per share are most preferred. This is consistent with the findings in Matsumoto et al. (1995) who surveyed analysts in the U.S. In their study, analysts ranked EPS and sales growth rates as the most important financial ratios for both retailers and manufacturing firms. Finally, according to results in Table 2, EBITDA is common across ratio categories. This is surprising, as EBITDA could be a misleading metric (Stumpp, 2000).

\section{Financial ratios and stock returns}

Table 5 provides regression results for all eight models with $t+4$ stock returns (i.e., 1 year future returns) as the dependent variable. The market return (BETA), to capture the firms' systematic betas from the market model (MacKinlay, 1997), and the natural logarithm of market capitalization

\footnotetext{
${ }^{9}$ While other ratios, such as working capital to sales and capital expenditures to depreciation and amortization, are important for cash flow analysis, they are used by J.P. Morgan and Credit Suisse only in this sample. Working capital to sales measures the efficiency of working capital investment management; and capital expenditures to depreciation and amortization captures the capability of management to maintain the firm "whole" (Hertenstein and McKinnon, 1997),
} 
Table 5

Leading stock returns regressed on most preferred financial ratios by equity analysts.

\begin{tabular}{|c|c|c|c|c|c|c|c|}
\hline Model 0 & Beta & Size & & & & & \\
\hline Estimate & $1.158^{* * *}$ & $-0.141^{\text {***** }}$ & & & & & \\
\hline $\mathrm{T}$ Value & 4.570 & -11.720 & & & & & \\
\hline Adj R2 & 0.116 & & & & & & \\
\hline Model 1 & Beta & Size & $F V E B$ & $E B M$ & $\operatorname{Div} Y$ & $D E Q$ & $E P S g$ \\
\hline Estimate & $1.159^{* * * *}$ & $-0.118^{\text {**** }}$ & $-0.002^{* * *}$ & $0.102^{* * *}$ & $-0.358^{* * * *}$ & $0.097^{* * *}$ & $0.011^{\text {**** }}$ \\
\hline $\mathrm{T}$ & 6.050 & -18.410 & -23.240 & 18.040 & -11.900 & 6.010 & 3.620 \\
\hline Adj R2 & 0.168 & & & & & & \\
\hline Model 2 & Beta & Size & $F V E B$ & $E B M$ & $\operatorname{Div} Y$ & $D E Q$ & Sales $g$ \\
\hline Estimate & $1.159^{* * * *}$ & $-0.119^{\text {**** }}$ & $-0.002^{* * * *}$ & $0.103^{* * *}$ & $-0.354^{* * * *}$ & $0.100^{* * *}$ & $0.010^{* * * *}$ \\
\hline $\mathrm{T}$ & 6.050 & -18.460 & -23.090 & 17.720 & -11.710 & 5.860 & 13.650 \\
\hline Adj R2 & 0.168 & & & & & & \\
\hline Model 3 & Beta & Size & $F V E B$ & $E B M$ & $F C F Y$ & $D E Q$ & $E P S g$ \\
\hline Estimate & $1.159^{* * *}$ & $-0.128^{* * * *}$ & $-0.002^{* * *}$ & $0.123^{* * *}$ & $-0.053^{* * *}$ & $0.092^{* * *}$ & $0.010^{* * * *}$ \\
\hline $\mathrm{T}$ & 5.990 & -19.970 & -22.410 & 21.170 & -11.350 & 5.680 & 3.210 \\
\hline Adj R2 & 0.167 & & & & & & \\
\hline Model 4 & Beta & Size & $F V E B$ & $E B M$ & $F C F Y$ & $D E Q$ & Sales $g$ \\
\hline Estimate & $1.158^{* * *}$ & $-0.129^{* * * *}$ & $-0.002^{* * *}$ & $0.125^{* * *}$ & $-0.054^{* * * *}$ & $0.095^{* * *}$ & $0.010^{* * * *}$ \\
\hline $\mathrm{T}$ & 5.990 & -20.030 & -22.270 & 20.710 & -11.390 & 5.540 & 13.550 \\
\hline Adj R2 & 0.167 & & & & & & \\
\hline Model 5 & Beta & Size & $F V E B$ & $R O I$ & $\operatorname{Div} Y$ & $D E Q$ & $E P S g$ \\
\hline Estimate & $1.152^{* * *}$ & $-0.130^{* * * *}$ & $-0.002^{* * *}$ & $0.059^{* * *}$ & $-0.446^{\text {**** }}$ & $0.058^{* * *}$ & $0.013^{\text {**** }}$ \\
\hline $\mathrm{T}$ & 5.810 & -19.940 & -22.860 & 10.100 & -14.780 & 3.710 & 4.140 \\
\hline Adj R2 & 0.158 & & & & & & \\
\hline Model 6 & Beta & Size & $F V E B$ & $R O I$ & $\operatorname{Div} Y$ & $D E Q$ & Sales $g$ \\
\hline Estimate & $1.151^{* * * *}$ & $-0.131^{* * * *}$ & $-0.002^{* * *}$ & $0.059^{* * *}$ & $-0.443^{* * * *}$ & $0.061^{* * * *}$ & $0.011^{* * * *}$ \\
\hline $\mathrm{T}$ & 5.800 & -20.020 & -22.660 & 10.010 & -14.600 & 3.670 & 14.140 \\
\hline Adj R2 & 0.157 & & & & & & \\
\hline Model 7 & Beta & Size & $F V E B$ & $R O I$ & $F C F Y$ & $D E Q$ & $E P S g$ \\
\hline Estimate & $1.150^{* * *}$ & $-0.144^{* * *}$ & $-0.002^{* * * *}$ & $0.063^{* * *}$ & $-0.045^{\text {**** }}$ & $0.04^{* *}$ & $0.012^{* * * *}$ \\
\hline $\mathrm{T}$ & 5.670 & -21.590 & -21.740 & 10.140 & -8.750 & 2.500 & 3.820 \\
\hline Adj R2 & 0.150 & & & & & & \\
\hline Model 8 & Beta & Size & $F V E B$ & $R O I$ & $F C F Y$ & $D E Q$ & Sales $g$ \\
\hline Estimate & $1.149^{* * * *}$ & $-0.145^{* * *}$ & $-0.002^{* * *}$ & $0.062^{* * *}$ & $-0.045^{* *}$ & $0.043^{* *}$ & $0.011^{\text {**** }}$ \\
\hline $\mathrm{T}$ & 5.670 & -21.670 & -21.540 & 10.060 & -8.790 & 2.520 & 14.320 \\
\hline Adj R2 & 0.149 & & & & & & \\
\hline
\end{tabular}

Stock returns are cumulative annual stock returns for 1 year. Beta is the systematic risk beta of the market model, Size is the natural logarithm of market capitalization, FV EB is firm value to EBITDA, EB M is EBITDA margin, ROI is return on investment, DivY is dividend yield, FCF Y is free cash flow Yield, DEQ is net debt to equity, EPS g is earnings per share growth, and Sales $\mathrm{g}$ is sales growth. Variables estimated as stated in Table 3. T and $\mathrm{P}$ are $t$-values and $p$-values respectively. $T$-values are corrected for serial correlation and heteroscedasticity using Newey-West estimator for standard errors. Variables estimated as stated in Table 3.

*** $1 \%$ statistical significance level.

** $5 \%$ statistical significance level. 
$(\log (M V E))$ are included to control for risk and size. ${ }^{10}$ In addition, we controlled by industry using industry dummies.

With the exception of the estimate for net debt to equity $(D E Q)$ in models 7 and 8 , all coefficients are statistically significant at $1 \%$ level. Furthermore, signs of coefficients are consistent across all eight models in Table $5 .^{11}$

The estimate for FV to EBITDA $(F V E B)$ is negative, consistent with the view that managers are pressured to decrease multiples every period so their stock be perceived by investors as less expensive. EBITDA margin ( $E B M$ ) and return on investment (ROI) are positive (e.g., higher profitability ratios and margins increase stock returns). Dividend yield (Div $Y$ ) is negative; when dividends are paid, stock price declines. Furthermore, firms with high dividend yields are generally large, stable, mature firms with low growth prospects. This result is consistent with our sample: mature, low growth stocks that are part of the Mexican Stock Exchange index. These equities are considered to be "value" stocks with the bulk of their value coming from dividend payouts rather than from price growth.

For FCF yield ( $F C F Y$ ), the negative sign could be explained by the free cash flow hypothesis (Jensen, 1986), which states that a higher free cash flow for a given price signals higher agency costs. The positive sign of net debt to equity implies that higher leverage increases firm value, as long as leverage is not unreasonably and unsustainably high (DEQ, for models 7 and 8 , is statistically significant at $5 \%$, unlike all coefficients/models, significant at $1 \%) .{ }^{12}$ Finally, the signs of EPS growth (EPS $g$ ) and Sales growth (Sales $g$ ) are positive, as expected given the direct pressure managers have on these metrics every quarter they disclosure financial statements.

Overall, these results provide evidence that the most preferred financial ratios used in practice by equity analysts following firms on the MSE have predictive power; with the signs of coefficients as predicted by financial theory. The marginal predictive power of these models (marginal to an asset pricing model), as expected, is not very high (model 0 , in Table 5, provides results of CAPM and size as control variable). It would not be possible to have a model with financial ratios having a high explanatory power, which would be the main purpose of asset pricing models, as stock price changes are very noisy.

As robustness tests (untabulated results), we also run regressions on the same variables, but using growth rates rather than levels. Results with growth variables are consistent with results with level variables. Furthermore, to test the persistency of results, we run regressions with the same variables using $t+8$ stock returns (i.e., 2-years future returns). We did not find evidence on the predictive power of these ratios as time passes. That is, the magnitude of the selected

\footnotetext{
10 The Fama and French 3 Factor Model (FF3) might be more appropriate to predict stock returns. FF3 is a stylized model including a market beta, firm size and book to market ratio as factors, with a very high predictive power for markets in developed economies. We do not use FF3 in this study because the factor loadings for this model are neither standardized nor readily available for firms trading in the MSE, as it is for developed economies. Since the use of an asset pricing model is not our main concern in this study, we only control for risk using beta and size to have a baseline model on which to build by adding the sets of selected financial ratios.

${ }^{11}$ When the models are run without the market beta and size parameter, all statistical significant parameters remain significant, and the adjusted $r$ square is about $11 \%$ (untabulated results).

12 While the optimal capital structure problem remains as one of the puzzles in corporate finance, it has been widely documented that debt increases value of firms due to several reasons, among them the tax shield of corporate taxes, and the commitment of fixed payment by debt that help to reduce agency costs, as long as these benefits are higher than the cost of leverage (e.g., financial distress costs). This is the argument of the tradeoff theory. At some point, an optimal level of debt is reached, and debt beyond that point decreases firm value.
} 
financial ratios at time $t$ could explain part of the variation of stock returns in $t+4$, but when new information arrives (1 year later), the new information is incorporated into stock prices.

\section{Conclusion}

In this study, we propose a set of the most preferred financial ratios used in practice by equity analysts covering Mexican publicly traded firms. Moreover, by using regression analysis, we test the relationship between financial ratios and leading stock returns.

We find that the set of most preferred financial ratios used in practice by equity analysts differs from what a typical financial textbook presents, especially pertaining to accounting ratios. Assuming that equity analysts represent a group of sophisticated users of financial information, other users (e.g., instructors, corporate managers) could use the results of this study, when conducting financial analysis, to: (1) use a reduced set of financial ratios, as opposed to a large number of ratios as used in practice, which would in turn reduce overlapping information, or (2) introduce the use of new financial ratios used by equity analysts but not in firms or in financial textbooks.

By regressing eight alternative models (with combinations of the most preferred financial ratios) on future stock returns, we find that financial ratios predict 1-year stock returns. All estimated coefficients are statistically significant after correcting for heteroscedasticity and autocorrelation. These results hold when stock returns 1 year ahead is used as the dependent variable. The predictive power of these ratios disappears with 2-year stock returns.

We recognize two main limitations in this study. First, a better asset pricing model might be needed as a benchmark to assess the predictive power of financial ratios. Factor loading, however, is neither standardized nor readily available for such asset pricing models in Mexico. Second, a larger sample of equity analyst reports may serve as a cross check for this study. To the best of our knowledge, however, a larger collection of recommendation reports by diverse equity analysts at any given point in time is not publicly available.

\section{Appendix 1. Mexican firms with equity analysts' recommendations available in ISI emerging markets as of Q1 2011}

\begin{tabular}{lllr}
\hline Firm & Industry & Mexican stock index & $\begin{array}{l}\text { Annual revenues (000 } \\
\text { USD) }\end{array}$ \\
\hline Alfa & & & $11,044,452.7$ \\
Alsea & Industrial conglomerates & Yes & $724,517.3$ \\
America Movil & Retail & No & $49,220,677.4$ \\
ARA & Media and telecommunications & Yes & $596,861.5$ \\
& Consumer brands \& retail & Yes & \\
Arca & household durables & & $2,191,183.8$ \\
ASR - Gpo Aer. Sureste & Beverages & Yes & $342,964.3$ \\
Axtel & Airport services & No & $862,534.9$ \\
Bimbo & Media and telecommunications & Yes & $9,487,216.8$ \\
BOLSA & Food-bakery & Yes & $138,199.1$ \\
Cemex & Financial services & Yes & $14,434,450.9$ \\
Chedraui & Construction & Yes & $4,121,345.8$ \\
Coca-Cola Femsa & Retail & Yes & $8,377,294.3$ \\
Compartamos & Beverages & Yes & $494,666.1$ \\
FAMSA & Financial & Yes & $1,214,037.5$
\end{tabular}




\begin{tabular}{|c|c|c|c|}
\hline Firm & Industry & Mexican stock index & $\begin{array}{l}\text { Annual revenues }(000 \\
\text { USD) }\end{array}$ \\
\hline FEMSA & Beverages & Yes & $13,741,481.9$ \\
\hline Genomma & $\begin{array}{l}\text { Consumer brands \& retail } \\
\text { household durables }\end{array}$ & Yes & $507,192.2$ \\
\hline GEO & Engineering \& construction & Yes & $1,551,015.7$ \\
\hline Gpo Aer del Centro & Airport services & No & $941,570.0$ \\
\hline Gruma & Food & Yes & $3,773,445.1$ \\
\hline Grupo Carso & Industrial conglomerates & No & $5,198,233.9$ \\
\hline Grupo KUO & Industrial conglomerates & No & $1,824,139.2$ \\
\hline Grupo Mexico & Mining & Yes & $8,320,141.6$ \\
\hline HERDEZ & Food and beverages & No & $718,343.9$ \\
\hline HOMEX & $\begin{array}{l}\text { Building materials \& } \\
\text { construction }\end{array}$ & Yes & $1,591,331.6$ \\
\hline ICA & Construction \& engineering & Yes & $2,831,287.2$ \\
\hline Kimberly & Consumption & Yes & $2,121,244.3$ \\
\hline Liverpool & Retail & Yes & $4,231,906.5$ \\
\hline Maxcom Telecom & $\begin{array}{l}\text { Diversified communication } \\
\text { services }\end{array}$ & No & $208,702.5$ \\
\hline Megacable & Telecoms, media \& technology & No & $608,059.8$ \\
\hline Mexichem & Petrochemical & Yes & $2,953,265.6$ \\
\hline MODELO & Beverages-alcoholic & Yes & $6,884,335.6$ \\
\hline PAC-Gpo Aer Pacifico & Airport services & Yes & $354,154.7$ \\
\hline SARE & Construction & No & $189,594.9$ \\
\hline SORIANA & Retail & Yes & $7,587,301.0$ \\
\hline Televisa & Radio \& TV broadcasting & Yes & $4,684,915.1$ \\
\hline Telmex & Media and telecommunications & Yes & $9,195,712.0$ \\
\hline TMM & Transportation services & No & $306,192.2$ \\
\hline TV Azteca & Radio \& TV broadcasting & Yes & $935,569.1$ \\
\hline URBI & Construction & Yes & $1,212,738.6$ \\
\hline Walmart de Mexico & Retail & Yes & $27,195,811.8$ \\
\hline
\end{tabular}

\section{References}

Arellano, M. (1987). Practitioners' corner: Computing robust standard errors for within-groups estimators. Oxford Bulletin of Economics and Statistics, 49, 431-434.

Barnes, P. (1987). The analysis and use of financial ratios: A review article. Journal of Business Finance \& Accounting, 14(4), 449-461.

Bates, T., Kahle, K., \& Stulz, R. (1999). Why do U.S. firms hold so much more cash than they used to? The Journal of Finance, $\operatorname{LXIV(5),1985-2021.}$

Beaver, W. (1966). Financial ratios as predictors of failure. Supplement to vol. 4 (Empirical Research in Accounting: Selected Studies). Journal of Accounting Research, 71-111.

Call, A. (2008). Analysts' cash flow forecasts and the predictive ability and pricing of operating cash flows. Available at SSRN: http://ssrn.com/abstract=1362177 or http://dx.doi.org/10.2139/ssrn.1362177

Call, A., Chen, S., \& Tong, Y. (2009). Are analysts' earnings forecast more accurate when accompanied by cash flow forecasts? Review of Accounting Studies, 14, 358-391.

Chen, K., \& Shimerda, T. (1981). An empirical analysis of useful financial ratios. Financial Management Spring, 51-60.

Delen, D., Kuzey, C., \& Uyar, A. (2013). Measuring firm performance using financial ratios: A decision tree approach. Expert Systems with Applications, 40(10), 3970-3983.

Fama, E., \& French, K. (1992). The cross-section of expected stock returns. Journal of Finance, 2, 427-465.

Gibson, C. (1987). How chartered financial analysts view financial ratios. Financial Analyst Journal, 43(3), 74-76. 
Hertenstein, J., \& McKinnon, S. (1997). Solving the puzzle of the cash flow statement. Business Horizons, (January-February), 68-76.

Jensen, M. (1986). Agency costs of free cash flow, corporate finance, and takeovers. American Economic Review, 76(2), 323-329.

Katchova, A., \& Enlow, S. (2013). Financial performance of publicly-traded agribusinesses. Agricultural Finance Review, $73(1), 58-73$.

Lewellen, J. (2004). Predicting returns with financial ratios. Journal of Financial Economics, 74, 209-235.

MacKinlay, C. (1997). Event studies in economics and finance. Journal of Economic Literature, 35(1), 13-39.

Matsumoto, K., Shivaswamy, M., \& Hoban, J. (1995). Security analysts' views of the financial ratios of manufactures and retailers. Financial Practice and Education, (Fall/Winter), 44-55.

Stumpp, P. (2000). Putting EBITDA in perspective: Ten critical failings of EBITDA as the principal determinant of cash flow. Moody's Investors Service,. Special comment http://www.moodys.com/cust/default.asp. (Last accessed November 2006)

Wang, Y., \& Lee, H. (2010). Evaluating financial performance of Taiwan container shipping companies by strength and weakness indices. International Journal of Computer Mathematics, 87(1), 38-52. 